\title{
Mineralization of Organic Residues, Dynamics of Microbial Biomass and Enzyme Activities in an Aridisol and Alfisol Soil under Rain-Fed Dry Farming
}

\section{Rehmat Ullah*1, Shehzada Munawar Mehdi' ${ }^{2}$ Khalid Saif Ullah Khan ${ }^{1}$, Aftab Ahmed Sheikh ${ }^{2}$, Endang Sulistyowati ${ }^{3}$, and Muhammad Saud ${ }^{4}$}

${ }^{1}$ Dept. of Soil Science \& Soil and Water Conservation, Pir Mehr Ali Shah, Arid Agriculture University, Rawalpindi, Pakistan.

2 Directorate of Soil Fertility Survey \& Testing Institute, Thokar Niaz Baig, Lahore, Pakistan. 3Department of Animal Science, Faculty of Agriculture, University of Bengkulu, Indonesia. ${ }^{4}$ Department of Sociology, Universitas Airlangga, Surabaya, Indonesia.

*Email address: rehmat1169@yahoo.com

\begin{abstract}
This study was planned with hypothesis to quantify mineralization rate of wheat and groundnut straw spiked in Kahuta and Guliana soil series. Results revealed that groundnut and wheat strawspiked soils had increased quantum of microbial biomass carbon $\left(\mathrm{C}_{\mathrm{mic}}\right)$, biomass nitrogen $\left(\mathrm{N}_{\mathrm{mic}}\right)$ and biomass phosphorous $\left(\mathrm{P}_{\mathrm{mic}}\right)$ and activities of enzyme dehydrogenase (DHA) and alkaline phosphatase (APA) than un-amended soils. Initially, the contents of soil $\mathrm{C}_{\text {mic }}, \mathrm{N}_{\text {mic, }} \mathrm{P}_{\text {mic, }}$ DHA, and APA increased gradually during 2-14th days of incubation (DAI), again increased significantly at $28^{\text {th }}$ DAI and then decreased slowly at $60^{\text {th }}$ DAI in all treatments under both series. Hence, the addition of groundnut straw mineralized better than to other organic sources in both soil series. These results suggested that groundnut straw must be incorporated in soil one month before sowing of crop to enhance crop yield under rain-fed dry farming.
\end{abstract}

Keywords: Crop Residues, Microbial Biomass, Soil Enzymes, Aridisol, Alfisols

Citation to this paper should be made as follows:

Ullah, R., S. M. Mehdi, K. S. U. Khan, A. A. Sheikh, E. Sulistyowati, and M. Saud. 2018. Mineralization of Organic Residues, Dynamics of Microbial Biomass and Enzyme Activities in an Aridisol and Alfisol Soil under Rain-Fed Dry Farming. Agritropica: Journal of Agricultural Science. 1 (1): 25-36. DOI: https://doi.org/10.31186/J.Agritropica.1.1.25-36

\section{INTRODUCTION}

Soil microorganisms play crucial roles in biogeochemical cycling and ecosystem functioning (Green \& Bohannan, 2006), and thus influence soil fertility under salt affected (Ullah et al., 2012) and normal soil conditions (Ullah et al., 2012). Therefore microbial biomass and various enzymatic activities are often measured to provide exact information about small changes in soils (He et al., 2008; 2009) and under various cropping systems (Ullah et al., 2012). Microbial biomass (Fliebach et al., 2007 and Ullah et al., 2013) and soil enzyme activities have been proposed as potential sensitive indicators to reveal changes of soil quality (Yang et al., 2008) and soil properties (Ross et al., 2003) on various soil water variation on slope gradient areas (Ullah et al., 2009). In arid environment, application of crop residues stimulates the microbial biomass size (Gaofei et al., 2010). Soil fertility could be maintained by the mineralization of crop residues. However, straw mineralization in soil significantly affects the storage of nutrient index in soil because of the interactions of temperature and moisture on plant productivity. The plant productivity is matched linearly and directly with the soil productivity. 
However, soil productivity primarily depends on its soil biological health, which reflects the magnitude of soil microbial biomass $C$, soil microbial biomass $\mathrm{N}$, soil microbial biomass $\mathrm{P}$ and enzymatic activities (Kawabiah et al., 2003). In present scenario, the exhaustive and intensive cropping systems on arid areas have endangered the health of soil ecosystem and its services as well. The preservation and sustainable utilization of soil ecosystem services is one of the key burning questions confronted to soil scientists across the globe (Foley et al., 2005 and Shah et al., 2015).

In agricultural areas of Pakistan under rainfed dry farming (Ullah et al., 2012), poor soil fertility (Khan, 2001) is one of the major limitations affecting crop production (Khan, 2001). Until now, the practice of applying organic amendments such as cereal and legume straws, to improve the content of soil organic matter for the maintenance of soil fertility has been rarely adopted in Pakistan. Except soil physico-chemical characteristics, the soil microbial properties in the moisture stressed soils have been less studied (McGrath et al. 1995). Some studies have revealed adverse effects of moisture stress on soil microbial biomass and enzymes activities (Kawabiah et al., 2003 and He et al., 2009). Various other studies contributed significant role of crop residues in soil biological health and quality (Ortega, et al., 2007; Ambus and Jensen, 2007; Chand et al., 2006; Antonio et al., 2007 and Carina et al., 2008).

However, keeping in view of soil fertility build up on moisture limited availability due to soil microbial biomass through the mineralization of crop resides on sustained basis. A hypothesis was executed to monitor the mineralization of applied crop residues under moisture stress conditions in soils. In this regards, two different organic substrates (wheat and groundnut straw) at $1 \%$ application rate were tested for their rates of decomposition and impact on soil biological properties in different soil series.

\section{RESEARCH METHODS}

\section{Collection of soils, crop residues and their analyses}

Soil samples of Guliana and Kahuta soil series (Aridisols and Alfisols) were collected from the agricultural fields under wheat-maize and wheat-mungbean crop rotations near the Kahuta in Northern Punjab, Pakistan. Sampling sites posses our distinct seasons i.e., summer season from June to August with maximum temperature up to $43^{\circ} \mathrm{C}$, the winter season from October to February with minimum temperature as low as $4^{\circ} \mathrm{C}$, spring and autumn season repectively. Uneven rainfall distribution and mean annual precipitation varies from 975 to $1050 \mathrm{~mm}$. The soils were sampled randomly at $0-30 \mathrm{~cm}$ soil depth from three locations of the fields by soil augar $(4 \times 15 \mathrm{~cm})$, brought to the laboratories of the Department of Soil Science \& SWC, PMAS-Arid Agriculture University Rawalpindi, Pakistan, passed through a $2 \mathrm{~mm}$ sieve and homogenized. A part of each soil sample was air-dried, ground, and analyzed for some physic-chemical properties given in Table 1. Wheat leaf straw (Triticum aestivem L.) and the groundnut straw (Arachus hypogea)used in the experiment were collected, dried at $65^{\circ} \mathrm{C}$ in a hot air oven ground and passed through a $0.5 \mathrm{~mm}$ screen before their addition to the soils. Soil textural analysis was carried out using Bouyoucos Hydrometer method as described by Black (1965) and the soil textural class was determined using Triangle from USDA (Gee \& Bauder, 1986). The $\mathrm{pH}$ of saturated soil paste was measured using soil $\mathrm{pH}$ meter having combination electrode (Mc Lean, 1982). Electrical conductivity (EC) was determined in the soil extracts taken from the saturated soil paste using a conductivity meter (Rhoades, 1982). 
Table 1 Properties of Guliana and Kahuta soil series used in the incubation experiment

\begin{tabular}{lcc}
\hline \multicolumn{1}{c}{ Properties } & Guliana Soil Series & Kahuta Soil Series \\
\hline Textural Class & Sandy Loam & Sandy Clay Loam \\
$\mathrm{pH}_{\mathrm{s}}$ & $7.45 \pm 0.03$ & $6.98 \pm 0.10$ \\
Electrical Conductivity $\left(\mathrm{d} \mathrm{Sm}^{-1}\right)$ & $0.36 \pm 0.09$ & $0.26 \pm 0.02$ \\
Total Soluble Salts (meq L-1) & $3.6 \pm 0.07$ & $2.6 \pm 0.03$ \\
Soil Organic Carbon (\%) & $1.01 \pm 0.15$ & $0.39 \pm 0.01$ \\
Total N (\%) & $0.08 \pm 0.01$ & $0.033 \pm 0.001$ \\
Available P (\%) & $5.2 \pm 0.42$ & $4.75 \pm 0.91$ \\
Extractable K $(\%)$ & $4.61 \pm 1.71$ & $3.3 \pm 0.37$ \\
\hline
\end{tabular}

${ }^{ \pm} \mathrm{SD}=\mathrm{Standard}$ Deviation among the median value

The Exchangeable soil potassium and sodium in the extracts was determined by a flame photometer (Knudsen et al., 1982). Available $\mathrm{P}$ in the $0.5 \mathrm{M} \mathrm{NaHCO}$ ( $\mathrm{pH}$ 8.5) extracts was determined using a spectrophotometer (Olsen and Sommers, 1982). Soil organic carbon was measured by dichromate digestion method (Page et al., 1982). Total nitrogen in soil was determined by Kjeldahl method after soil digestion with concentrated $\mathrm{H}_{2} \mathrm{SO}_{4}$ and the digestion mixture $\left(\mathrm{K}_{2} \mathrm{SO}_{4}: \mathrm{FeSO}_{4}: \mathrm{CuSO}_{4}\right.$ : 10.0:1.0:0.5) (Buresh et al., 1982).

\section{Incubation procedure}

The soils were adjusted to $40 \%$ of their water holding capacity, homogenized, and preincubated at room temperature for 2 weeks prior to treatment application. The treatments included: $\mathrm{T}_{0}=$ Control, $\mathrm{T}_{1}=$ Soil + groundnut straw $(1 \% \mathrm{w} / \mathrm{w})$, and $\mathrm{T}_{2}=$ Soil + wheat straw $(1 \% \mathrm{w} / \mathrm{w})$. For each treatment, $1.0 \mathrm{~kg}$ (oven-dry basis) soil was placed in quadruplicate into $3 \mathrm{~L}$ incubation vessels. Treatments were applied, moisture contents were adjusted to $50 \%$ water holding capacity and the incubation vessel were tightly closed and incubated for 60 days at $25{ }^{\circ} \mathrm{C}$ in the dark. The $\mathrm{CO}_{2}$ evolved was absorbed in $1 \mathrm{M} \mathrm{NaOH}$ solution and analyzed by back-titration with $1 \mathrm{M} \mathrm{HCl}$ after 2, 4, 7, 14, 28 and 60 days of incubation. Soil samples (50 g oven dry weight) were collected after $2,4,7,14$, 28 and 60 days after incubation and analyzed for microbial biomass $\mathrm{C}, \mathrm{N}, \mathrm{P}$ and enzyme activities (dehydrogenase and alakaline phosphatase).

\section{Microbial biomass carbon $\left(\mathrm{C}_{\mathrm{mic}}\right)$ and nitrogen $\left(\mathbf{N}_{\text {mic }}\right)$ Determination}

Microbial biomass $\mathrm{C}$ and biomass $\mathrm{N}$ were estimated by fumigation-extraction (Brookes et al., 1985) in the $50 \mathrm{~g}$ samples removed from each of the incubation beakers. Fumigated and non-fumigated soil sample were extracted with $40 \mathrm{ml} 0.5 \mathrm{M} \mathrm{K}_{2} \mathrm{SO}_{4}$ by 30 min horizontal shaking at $200 \mathrm{rev} \mathrm{min}^{-1}$ and filtered through a folded filter paper (Whatman No. 40). Organic $C$ in the extracts was measured as $\mathrm{CO}_{2}$ by infrared absorption after combustion at $760{ }^{\circ} \mathrm{C}$ using a Shimadzu automatic TOC analyzer model 5050 Japan. Microbial biomass $\mathrm{C}$ was calculated as follows: Microbial biomass $C=E c / k_{E C}$. Where $E c=$ (organic C extracted from fumigated soils) (organic $\mathrm{C}$ extracted from non-fumigated soils) and $\mathrm{K}_{\mathrm{EC}}=0.45$ (Anderson \& Ingram, 1993).

Similarly, Total $\mathrm{N}$ in the extracts was measured as $\mathrm{NO}_{2}$ after combustion at $760{ }^{\circ} \mathrm{C}$ using a Shimadzu-N chemo luminescence detector model 5050 (Shimadzu Corp. Japan). Microbial biomass $\mathrm{N}$ was calculated as follows: Microbial biomass $\mathrm{N}=\mathrm{E}_{\mathrm{N}} / k_{\mathrm{EN}}$. Where $\mathrm{E}_{\mathrm{N}}=$ (total $\mathrm{N}$ extracted from fumigated soils) - (total $\mathrm{N}$ extracted from non-fumigated soils) and $k_{\mathrm{EN}}$ $=0.54$ (Brookes et al., 1985). 


\section{Microbial biomass P Determination}

The soil microbial biomass phosphorous was also measured by fumigation-extraction technique (Brookes et al., 1982). A sub sample of $15 \mathrm{~g}$ soil was taken from the $50 \mathrm{~g}$ representative soil sample of the incubation and divided into three portions equivalent to 5 g soil. Fumigant, non-fumigant and $25 \mu \mathrm{g} \mathrm{P} \mathrm{g-1}$ added were extracted with $100 \mathrm{ml}$ of $0.5 \mathrm{M}$ $\mathrm{NaHCO}_{3}$ (pH 8.5) by horizontal shaking for 30 $\mathrm{min}$ at $200 \mathrm{rev} \mathrm{min}^{-1}$, then the soil suspension was centrifuged for $15 \mathrm{~min}$ at (2000 rev) and filtered. The phosphorous was analyzed by a modified ammonium molybdate ascorbic acid method (Joergensen \& Muller, 1995). The microbial biomass phosphorous was $E_{\mathrm{p}} / k_{\mathrm{EP}} /$ recovery, where $E_{\mathrm{p}}=\left(\mathrm{PO}_{4}-\mathrm{P}\right.$ extracted from fumigated soil) - $\left(\mathrm{PO}_{4}-\mathrm{P}\right.$ extracted from nonfumigated soil) and $k_{\mathrm{EP}}=0.40$ (Brookes et al., 1982).

\section{Soil Alkaline Phosphatase activity}

One gram soil was mixed with $0.2 \mathrm{ml}$ toluene, $4 \mathrm{ml}$ of MUB (modified universal buffer) of $\mathrm{pH} 11,1 \mathrm{ml}$ of p-nitrophenyl phosphatase solution and flask was placed in an incubator at $37{ }^{\circ} \mathrm{C}$ for 24 hours. Then, $1 \mathrm{ml}$ of $0.5 \mathrm{M} \mathrm{CaCl}_{2}$ and $4 \mathrm{ml}$ of $0.5 \mathrm{~N} \mathrm{NaOH}$ were added and soil suspension was filtered through a Whatman No. 20 folded filter paper. Yellow color intensity was measured at $400 \mathrm{~nm}$ wavelength by using a spectrophotometer (Eivazi \& Tabatabai, 1977).

\section{Soil Dehydrogenase activity}

Air dried soil was mixed with $0.2 \mathrm{~g}$ of $\mathrm{CaCO}_{3}$ and $6 \mathrm{~g}$ of this mixture was placed in each of the three test tubes. One $\mathrm{ml}$ of $3 \%$ aqueous solution of TTC (triphenyl tetrazolium chloride) and $2.5 \mathrm{ml}$ of distilled water, samples were incubated at $37{ }^{\circ} \mathrm{C}$. Thereafter, $10 \mathrm{ml}$ of methanol was added and filtered after shaking. The red color intensity was measured by using a spectrophotometer at a wavelength of $485 \mathrm{~nm}$ (Casida et al., 1964).

\section{Data analyses}

The data obtained were analyzed statistically following analysis of variance (ANOVA) technique and the Duncan's Multiple Range (DMR) test was applied to compare the treatment means according to Steel et al., (1997).

\section{RESULTS}

\section{Microbial biomass carbon $\left(\mathrm{C}_{\text {mic }}\right)$}

Its median contents (Figure 1) varied significantly $(P \leq 0.05)$ among all the treatments but remained non-significant $(P \geq 0.05)$ in nonamended soils. The soil spiked with groundnut straw and wheat straw had attained more median contents as compared to farmer practice. Higher strength was found higher in $\mathrm{T}_{2}(7.12 \& 20.93 \%)$ and $\mathrm{T}_{1}(11.47 \& 27.78 \%)$ than to natural $\left(\mathrm{T}_{0}\right)$ soil environmental conditions during the whole incubation processes at Kahuta and Gulian soil series. Its median contents increased linearly in all treatments at both soil series. This response was quite contrary to other scientist's published findings. Its increasing behavior in all treatments of both soil series has been found in this pattern; initially increased gradually from 2 to $14^{\text {th }}$ days; enhanced significantly $(P<0.05)$ from $28^{\text {th }}$ days; and then decreased at $60^{\text {th }}$ days of incubation process very slowly. Among both soil series, Kahuta soil series had stored more $\mathrm{C}_{\text {mic }}$ median content as compared to Guliana soil throughout the entire incubation processes. Data revealed that $T_{2}$ has given more $C_{\text {mic }}$ median content as compared to $T_{1}$ and $T_{0}$ respectively in both soil series at $28^{\text {th }}$ days of incubation process as compared to all other days.

\section{Microbial Biomass Nitrogen $\left(\mathbf{N}_{\text {mic }}\right)$}

The microbial biomass nitrogen $\left(\mathrm{N}_{\text {mic }}\right)$ data of Guliana and Kahuta soil series (Figure 2) avowed a variable trend for rate of mineralization of wheat and groundnut straw on soil fertility dynamics. The natural soil 
environmental condition ( $\left.\mathrm{T}_{0}\right)$ had shown nonsignificant $(P \geq 0.05)$ impact on storage of $\mathrm{N}_{\text {mic }}$ median contents; while straw amendments had

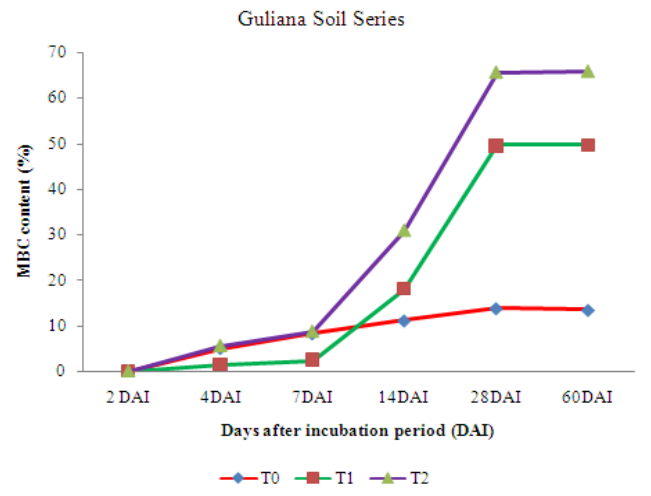

shown restorative effect in this regard. More $\mathrm{N}_{\text {mic }}$ median contents in both soil series has been found in $T_{2}$ as compared to $T_{1}$ and $T_{0}$.

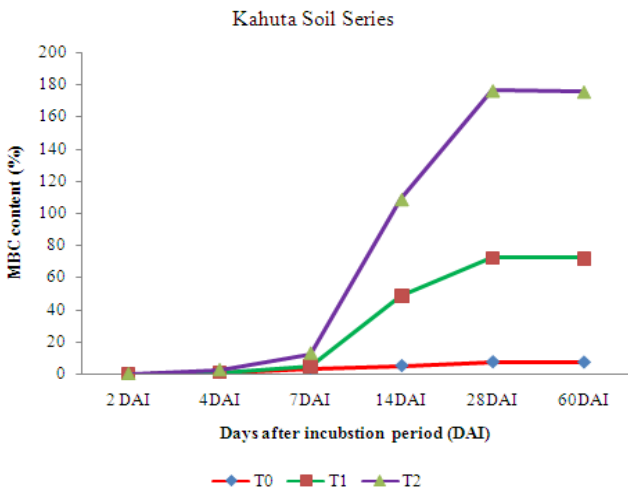

Figure 1 Impact of crops residues addition on microbial biomass $\mathrm{C}$ contents in Guliana and Kahuta soil series

It remained overall high in $\mathrm{T}_{2}(43.76 \&$ $30.83 \%)$ and $\mathrm{T}_{1}(46.69 \& 41.17)$ than to natural $\left(\mathrm{T}_{0}\right)$ soil environmental conditions during the whole incubation processes at Kahuta and Gulian soil series. Initially, it increased gradually from 2 to $14^{\text {th }}$ days; then enhanced significantly $(P<0.05)$ from $28^{\text {th }}$ days; and then decreased at $60^{\text {th }}$ days of incubation process very slowly. Kahuta soil series had stored more $\mathrm{N}_{\text {mic }}$ median content as compared to Guliana soil throughout the entire incubation processes.

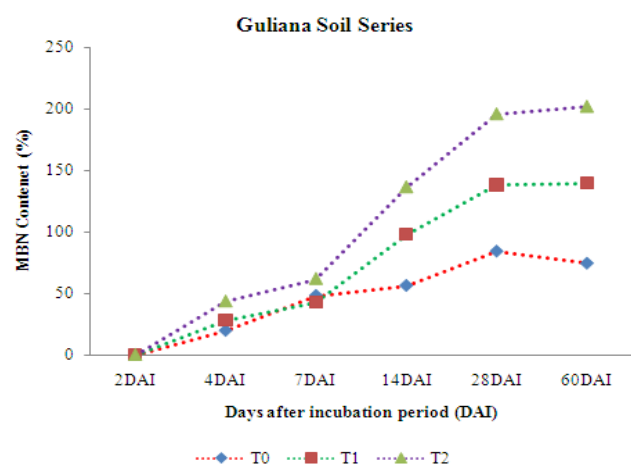

Figure 2 Effect of crops residues addition on microbial biomass $\mathbf{N}$ contents in Guliana and Kahuta soil series

\section{Microbial biomass phosphorous $\left(\mathbf{P}_{\text {mic }}\right)$}

Microbial biomass phosphorous ( $\left.\mathrm{P}_{\mathrm{mic}}\right)$ of Kahuta and Guliana soil series (Figure 3) responded a heterogenic impact. During the incubation period, the control treatment did not show a significant impact on the availability of soil $\mathrm{P}_{\text {mic }}$ but the wheat and groundnut straws
$\mathrm{T}_{2}$ has given more $\mathrm{N}_{\text {mic }}$ median content as compared to $T_{1}$ and $T_{0}$ respectively in both soil series at $28^{\text {th }}$ days of incubation process as compared to all other days. It might be attributed to active participation of enzymatic activities due to favorable conditions availability for the mineralization of straw spiked in soil consortia. Hence, availability of organic substrate to the microbial community is converted into the nutrient flux for the growth and developments of crop.

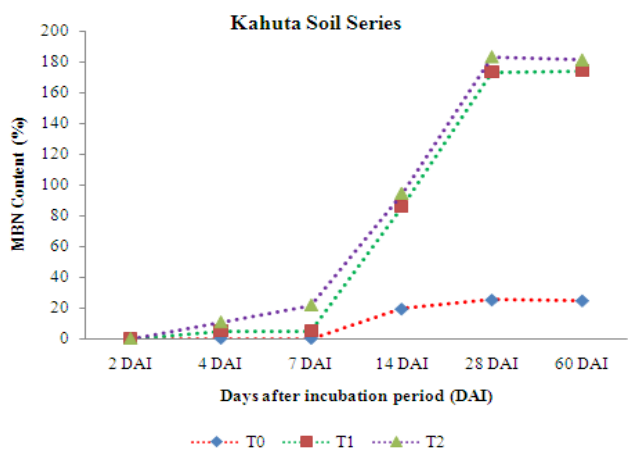

application showed an aggressive effect. In general, more $P_{\text {mic }}$ median contents were available in both soil series where groundnut and wheat straw have been incorporated. Generally, it was found higher in $\mathrm{T}_{2}(12.25$ \& $27.02 \%)$ and $\mathrm{T}_{1}(14.91 \& 31.23)$ than to natural $\left(\mathrm{T}_{0}\right)$ soil environmental conditions during the whole incubation processes at Kahuta and 
Gulian soil series respectively. Generally, it increased gradually from 2 to $14^{\text {th }}$ days, then enhanced significantly $(P<0.05)$ from $28^{\text {th }}$ days and then decreased at $60^{\text {th }}$ days of incubation process very slowly. Kahuta soil series had stored more $\mathrm{P}_{\text {mic }}$ median content as compared to Guliana soil throughout the entire incubation processes. The data revealed that $T_{2}$ has given more $P_{\text {mic }}$ median content as compared to $T_{1}$ and $T_{0}$ respectively in both soil series at $28^{\text {th }}$ days of incubation process as compared to all other days. Efficient and active enzymes activities such as alkaline phosphatase and soil biological status under favorable circumstances had contributed a significant role for the availability of $P_{\text {mic }}$ which is a basic requirement for the growth and development of crop.

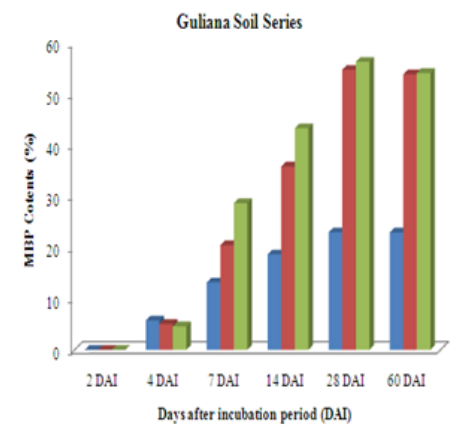

แT0 $\backsim \mathrm{T} 1 \Perp \mathrm{T} 2$

\section{Dehydrogenase ( $\mu$ g TPF g-1 soil) activity}

Dehydrgenase (DHA) activity (Figure 4) of both two soil series reflected significant indicator in this study. During the entire incubation period, the farmer practice (no straw application) treatment had non significant $(P \geq 0.05)$ impact on the activity of $\mathrm{DH}$ where as wheat and groundnut straws amendments had activated more dehydrogenase effectiveness. The effective activity of $\mathrm{DH}$ was observed in soils series which were spiked by groundnut straw and wheat straw. In general, farmer practice has lower (11.61 and $26.82 \%$ ) activities than to groundnut and wheat straw respectively at Kahuta soil series. However, its activity was also lower (14.05 to $16.07 \%$ ) in farmer practice as compared to $T_{2}$ and $T_{1}$ at Guliana soil series. It is best indicator against the polluted soil environments.

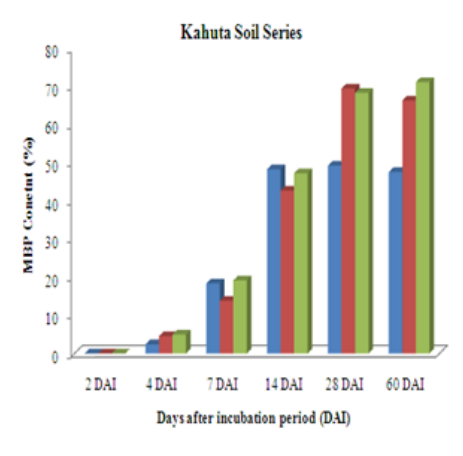

แT0 $=\mathrm{T} 1$ =T2

Figure 3 Impact of crops residues addition on microbial biomass P contents in Guliana and Kahuta soil series
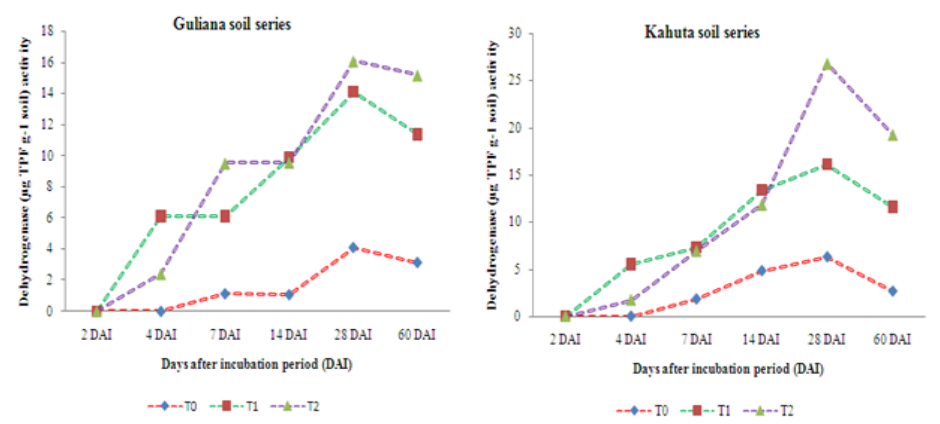

Figure 4 Dehydrogenase ( $\mu$ g TPF g-1 $^{-1}$ soil) activity in Guliana and Kahuta soil series

Its activity responded in this fashion; initially increased gradually from 2 to $14^{\text {th }}$ days, then enhanced significantly $(P<0.05)$ from $28^{\text {th }}$ days and then decreased at $60^{\text {th }}$ days of incubation process very slowly. $\mathrm{DH}$ activity was found more in Kahuta soil series as compared to Guliana soil throughout the entire incubation processes. The data also advocated that $\mathrm{T}_{2}$ has enhanced more $\mathrm{DH}$ activity as compared to $\mathrm{T}_{1}$ and $\mathrm{T}_{0}$ respectively in both soil 
series at $28^{\text {th }}$ days of incubation process as compared to all other days. The $\mathrm{DH}$ is very sensitive to heavy metal strength and showed a positive relation to the straw spiked soils due to availability of favorable circumstances.

\section{Alkaline Phosphatase ( $\mu \mathrm{g}$ p-NP $\mathrm{g}^{-1}$ soil 24h-1)}

Effective activity of alkaline phosphates (Figure 5) was observed where organic amendment of groundnut and wheat straw has been applied as compared to farmer practice (control treatment) in soils of both series. In general, its activity was found lower from 70.39 and $25.74 \%$ in $\mathrm{T}_{0}$ as compared to $\mathrm{T}_{2} \& \mathrm{~T}_{1}$ at Kahuta soil series respectively. Similarly, its activity was also lower (19.81 and 33.66) in $\mathrm{T}_{0}$ as compared to $T_{2} \& T_{1}$ at Guliana soil series respectively. APA activity is best indicator for the phosphorous availability in the soil. Its quantum efficacy of all treatments of both soil series responded in this regard; initially increased gradually from 2 to $14^{\text {th }}$ days, then enhanced significantly $(P<0.05)$ from $28^{\text {th }}$ days and then decreased at $60^{\text {th }}$ days of incubation process very slowly. $\mathrm{T}_{2}$ has enhanced more $\mathrm{DH}$ activity as compared to $T_{1}$ and $T_{0}$ respectively in both soil series at $28^{\text {th }}$ days of incubation process as compared to all other days. The APA is precursor and substrate for the availability of $P_{\text {mic }}$ as an essential element for plant growth and productivity. It availability showed a positive relation to the straw spiked soils due to presence of suitable environment. Guliana soil series had more AP activity than to Kahuta soil series throughout the incubation period.
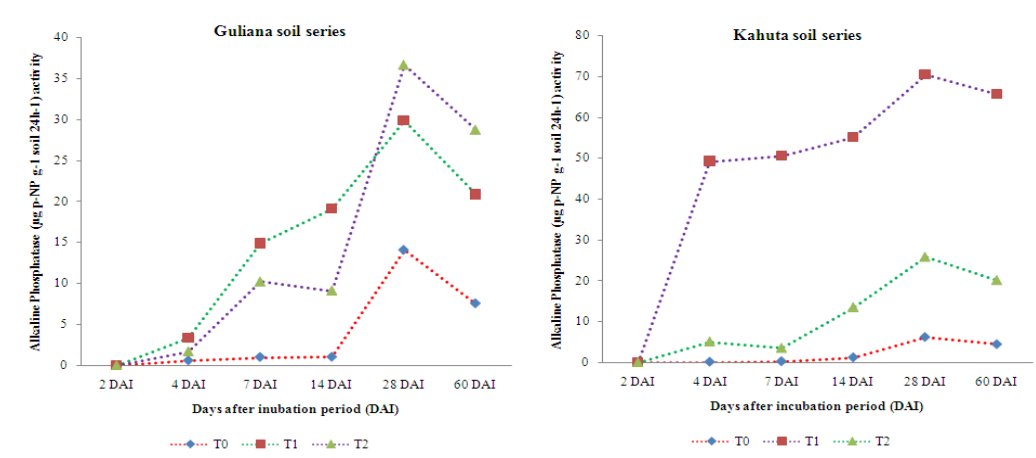

Figure 5 Alkaline Phosphatase ( $\mu \mathrm{g}$ p-NP g-1 soil $24 \mathrm{~h}^{-1}$ ) activity in Guliana and Kahuta soil series

\section{DISCUSSION}

In the control (non-amended) soil, the microbial biomass $\mathrm{C}$, biomass $\mathrm{N}$, biomass $\mathrm{P}$ remained lower during the incubation period and had not a significant impact on the soil biological properties as observed by others (Rietz \& Haynes, 2003; Ros et al., 2003; Marin, 2004). The addition of straw caused a net increase in all microbial properties. However, none of these increases revealed clear links to non amended straw soils in both soils under study. Consequently, the hypothesis stated was testified that addition of organic amendments had a higher impact on the mineralization of groundnut straw than wheat straw. It might be due to the difference in clay content in soil, organic matter content, and microbial biomass, the composition of the soil microbial population/community and the composition of organic substrate applied in soil. The lower levels of microbial biomass and soil organic material in the control (farmer practice) treatment were presumably and indirectly caused by a reduced crop growth and consequently a reduced $\mathrm{C}$ input in the soil (Joergensen, 2001). Initially, microbial biomass and enzymes activities were shown lower under both soil series. Their community/population increased linearly due 
to availability of substrate for mineralization process and optimum soil environmental condition like moisture and temperature. Annual crop plants can be colonized strongly by microbial organisms, especially during the period of maturity, which seem to play an important role for decomposition in soil (Flessa et al., 2002). When the living plant materials were added to soil, it cannot be completely ruled out that a part of the $\mathrm{CHCl}_{3}$-labile material would originate from still intact and living plant material (Hu et al., 2008). Tajeda et al., (2006) found that the application of organic amendment improved soil biological properties under optimum soil water availability.

The microbial biomass $C$ in both soil series had shown maximum values in groundnut straw application than wheat straw and non-amendment. Similar results were also observed by others (Potthoff et al., 2001; Hojati \& Norbaksh, 2006). Levels of microbial biomass $\mathrm{P}$ increased significantly in the $28^{\text {th }}$ day during incubation period in both soil series of arid climate. Initially, the lower contents were due to inactivation of $\mathrm{P}$ solublizing enzymes like alkaline phosphatase. Likewise, Ross et al. (2003) also noted the same data for $P_{\text {mic }}$ contents. Decrease in soil $\mathrm{N}$ due to lower organic materials would decline the soil fertility status (Tate, 1987). However, the similar results were observed by Liang et al. (2005). Some studies narrated that application of organic amendments did not contribute a significant impact on soil microbial biomass in arid areas. They strongly recommended that organic residues must not be incorporated in arid soil as they would not flourish the soil microbial biomass. Their findings were quite opposite to our investigation (Kawabiah et al., 2003 and He et al., 2009).

Incorporation of organic amendments to soil influences soil enzymatic activities (Burns, 1978) because added material may contain intra- and extra cellular enzymes and may also stimulate microbial activity in the soil (Pascual et al., 1998). According to Rao \& Pathak (1996) and Liang et al. (2005), their incorporation stimulated dehydrogenase activity and microbial activity in the soil (Liang et al., 2005). The higher level of dehydrogenase activity was noted in $28^{\text {th }}$ day during the incubation process being precursor for heavy metal presence and biodegradation process. Existence of novel environmental condition, $\mathrm{DH}$ activity has been seen more in the soil spiked with groundnut straw than to wheat and non-amended practice. The activity of soil enzymes could be inhibited by various kinds of organic amendments. Bomanti et al. (1985) have reported that the presence of heavy metals in waste water and sewage sludge were the inhibitory factors when the soil is amended soil was analyzed for dehydrogenase and alkaline phoisphatase activity. Similarly, the alkaline phosphatase activity was also observed in both soil series at 28 days during incubation process. The alkaline phosphatases are the basic prerequisite for the availability of microbial biomass $\mathrm{P}$ as a nutrient for the growth and development of crop plants. Demand for $\mathrm{P}$ by plants and soil microorganisms may have been responsible for the stimulation in the synthesis of this enzyme (Garcia et al., 1994). Likewise, Rao \& Tarafdar (1992), increases in phosphatase activity indicate changes in the quantity and quality of soil phosphoryl substrates. Our results indicated that soil enzymatic activities are slightly higher in soil amended by ground straw than to the wheat and non-amended soils that might be attributed to mineralization rate straw spiked soil. Various scientific investigations did not support to our results and suggested that application of crop residues of wheat straw are not best strategy for soil microbial biomass in arid areas (Kawabiah et al., 2003 and He et al., 2009).

\section{CONCLUSION}

Application of groundnut straw @ 1\% under dry farming conditions improved soil biological properties than wheat straw. Soil 32 | Ullah et al : Mineralization of Organic Residues, Dynamics of Microbial Biomass and Enzyme... 
microbial biomass and soil enzymatic activities were higher in groundnut straw $(1 \%)$ than wheat straw $(1 \%)$ amended soils, due to availability of suitable environment for the availability of labile fraction of organic matter. It was concluded that cover crops such as groundnut might be incorporated in soil one month before the sowing of the crop. This exercise would not only maintain the soil fertility status and soil biological health but would also conserve the soil water contents for subsequent use.

\section{ACKNOWLEDGMENT}

The author would acknowledge to Higher Education Commission, Islamabad for providing a project (HEC-669) as financial support for the completion of this study. I will also thankful to Department of Soil Science \&SWC, Pir Mehr Ali Shah Arid Agriculture University, Rawalpindi for providing technical assistance.

\section{REFERENCES}

Ambus, P., and E. S. Jensen. 2007. Crop residue management strategies to reduce N-losses-interaction with crop $\mathrm{n}$ supply. Communications in Soil Science and Plant Analysis 32(7-8): 981996.

Anderson, J. M., and J. S. I. Ingram. 1993. In Tropical Soil Biology and Fertility: $-A$ Handbook of Methods. CAB International, Wallingford, U. K. 68-71.

Antonio C. V. Motta, D. Wayne Reeves, Charles Burmester \& Y. Feng. 2007. Conservation tillage, rotations, and cover crop affecting soil quality in the Tennessee valley: particulate organic matter, organic matter, and microbial biomass. Communications in Soil Science and Plant Analysis 38(19-20): 2831-2847.

Black, C. A. 1965. Methods of Soil Analysis. American Society of Agronomy, Madison, Wisconsin, USA.
Brookes, P. C., A. Landman, G. Pruden, and D. S. Jenkinson. 1985. Chloroform fumigation and the release of soil nitrogen: A rapid direct extraction method for measuring microbial nitrogen in soil. Soil Biology $\mathcal{E}$ Biochemistry 17: 837-842.

Brookes, P. C., D. S. Powlson, and D. S. Jenkinson. 1982. Measurement of microbial biomass phosphorous in soil. Soil Biology \& Biochemistry 14: 319-329.

Buresh, R. J., E. R. Austin, and E. T. Craswell. 1982. Analytical method in N-15 research. California Fertilizer Association. Soil Improvement Committee, 1980. Western Fertilizer Handbook. 6th (ed) Interstate Printers and Publishers. Danville, ILL, USA. Fertilizer Research 3: 47-62.

Burns, R. G. 1978. Enzyme Activity in Soil. Some Theoretical and Practical Considerations. In R.G. Burns (ed.) Soil enzymes. Academic Press, New York. 295-340.

Casida, L. E., D. A. Klein, and T. Santro. 1964. Soil dehydrogenase activity. Soil Science Society of America Journal 98: 371-376.

Carina R., R. A. Álvarez, and A. Sarquis. 2008. Residue decomposition and fate of nitrogen-15 in a wheat crop under different previous crops and tillage systems. Communications in Soil Science and Plant Analysis 39(3-4): 574-586.

Chand, S., M. Anwar, D. D. Patra \& S. P. S. Khanuja. 2006. Effect of mint distillation waste on soil microbial biomass in a mint-mustard cropping sequence. Communications in Soil Science and Plant Analysis 35(1-2): 243-254.

Eivazi, F., and M. A. Tabatabai. 1977. Phosphatase in soils. Soil Biology $\mathcal{E}$ Biochemistry 9:167-172. 
Flessa, H., M. Potthoff, and N. Loftfield. 2002. Green house estimates of $\mathrm{CO} 2$ and $\mathrm{N} 2 \mathrm{O}$ emissions following surface application of grass mulch: importance of indigenous microflora of mulch. Soil Biology \& Biochemistry 345: 875-879.

Fliebach, A., H. R. Oberholzer, L. Gunst, and P. Mader. 2007. Soil organic matter and biological soil quality indicators after 21 years of organic and conventional farming. Agriculture, Ecosystems $\mathcal{E}$ Environment 118: 273-284.

Foley, J. A., R. DeFries, G. P. Asner, C. Barford, G. Bonan, S. R. Carpenter, F. S. Chapin, M. T. Coe, G. C. Daily, H. K Gibbs, J. H. Helkowski, T. Holloway, E. A. Howard, C. J. Kucharik, C. Monfreda, J. A. Patz, I. C. Prentice, N. Ramankutty, and P. K. Snyder. 2005. Global consequences of land use. Science Journal 309 (5734): 570-574.

Gaofei, G., L. Zhaojun, F. Fenliang, C. Guixin, H. Zhenana, and Yongchao. 2010. Soil biological activity and their seasonal variations in response to long term application of organic and inorganic fertilizers. Plant $\mathcal{E}$ Soil 326: 31-44.

Garcia, C., T. Hernandez, F. Costa, and B. Ceccanti. 1994. Biochemical parameters in soils regenerated by the addition of organic wastes. Waste Management and Research 12: 457-466.

Gee, G. W., and J. W. Bauder. 1986. Particle size analysis. In: Methods of Soil Analysis. Klute. A., (eds.). Part I. American Society of Agronomy, Madison, USA. 383.

Green, J., and B. J. M. Bohannan. 2006. Spatial scaling of microbial biodiversity. Trends in Ecology and Evolution 21: 501507.

He, J. Z., Y. Ge, Z. H. Xu, and C. R. Chen. 2009. Linking soil bacterial diversity to ecosystem multifunctional using backward elimination booted tree analyses. Journal of Soils Sediments 9: 547- 554 .

He, J. Z., Y. Zheng, C. R. Chen, Y. Q. He, and L. M. Zhang. 2008. Microbial composition band diversity of an upland red soil under long term fertilization treatments as revealed by culture-dependent and cultureindependent approaches. Journal of Soils Sediments 8: 349-358.

Hojati, S., and F. Nourbakhsh. 2006. Enzyme activities and microbial biomass $\mathrm{C}$ in a soil amended with organic and inorganic fertilizers. Journal of Agronomy 5: 563-579.

Hu, C., Z. P. Cao, Y. F. Chen, and R. Dawson. 2008. Dynamics of soil microbial biomass carbon, mineral nitrogen and nitrogen mineralization in long-term field experiment at Northern China. Journal of Sustainable Agriculture 32: 1044- 1046.

Joergensen, R. G, and T. Mueller. 1995. The fumigation extraction method to estimate soil microbial biomass: calibration of the $\mathrm{k}$ EN value. Soil Biology and Biochemistry 28: 33-37.

Joergensen, R. G. 2001. The fumigationextraction method to estimate soil microbial biomass: Calibration of the $\mathrm{kEC}$ value. Soil Biology and Biochemistry 28: 25-31.

Kawabiah, A. B, C. A. Palm, N. C. Stoskopf, and R. P. Voronhy. 2003. Response of soil microbial biomass dynamics to quality of plant materials with emphasis on $\mathrm{P}$ availability. Australian Journal of Soil Research 30: 800-832.

Khan, S. R. A. 2001. Crop management water in Pakistan with focus on soil and water. A book published for government of the Punjab Agriculture Department Lahore-Pakistan. 1-179.

Knudsen, D., G. A. Peterson, and P. F. Pratto. 1982. Lithium, Sodium and Potassium. In: A. L. Page, R. H. Miller and D. R. Keey

34 | Ullah et al : Mineralization of Organic Residues, Dynamics of Microbial Biomass and Enzyme... 
(eds). Methods of Soil Analysis Part 2. Amer. Soc. Agron. No.9. Madison, Wisconsin, USA. 228-238.

Liang, Y., M. Nikolic, Y. Peng, W. Chen, and Y. Jiang. 2005. Organic manure stimulates biological activity and barley growth in soil subject to secondary salinization. Soil Biology and Biochemistry 37: 1185-1195.

Marin, J. A. 2004. Biorremediacio' $n$, mediante te' cnicas biolo' gicas, de hidrocarburos contenidos en lodos de refinería. Experiencias en clima semia' rido. Ph.D. thesis (In German).

Mc Lean, E. O. 1982. Soil $p H$ and lime requirement. In A.L. Page (ed). Methods of Soil analysis, part 2: Chemicals and Microbiological properties. American Society of Agronomy Madison. WI, USA. 199-224.

McGrath, S. P., A. M. Chaudhri, and K. E. Giller. 1995. Long-term effects of metals in sewage sludge on soils, microorganisms, and plants. Journal of Industrial Microbiology 14: 94-104.

Olsen, S. R., and L. E. Sommers. 1982. Phosphorus. In A. L. Page (ed), Methods of soil analysis, Agron. No.9, Part 2: Chemical and Microbiological Properties, 2nd ed., American Soc. Agron. Madison, WI, USA. 403-430.

Ortega, R. A., D. G. Westfall, and G. A. Peterson. 2007. Climatic gradient, cropping system, and crop residue impacts on carbon and nitrogen mineralization in no-till soils. Communications in Soil Science and Plant Analysis 36(19-20): 2875-2887.

Page A L, Miller R H, Keeney D R. 1982. Methods of soil analysis. Part 2, Chemical and microbiological properties ASA. Monograph. No. 9, Madison, WI, USA.

Potthoff, M., R. G. Joergensen, and V. Wolters. 2001. Short term effects of earthworm activity and straw amendment on the microbial $\mathrm{C}$ and $\mathrm{N}$ turnover in a remoistened arable soil after summer drought. Soil Biology and Biochemistry 33: 583-591.

Rao, A. V., and J. C. Tarafdar. 1992. Seasonal changes in available phosphorus and different enzyme activities in arid soils. Annals of Arid Zone 31: 185-189.

Rao, D. L. N., and H. Pathak. 1996. Ameliorative influence of organic matter on the biological activity of salt affected soils. Arid Soil Research and Rehabilitation 10: 311-319.

Rhoades, J. D. 1982. Cation Exchange Capacity. In A.L., Page (ed.). Methods of Soil Analysis, Agronomy No. 9, Part 2: Chemical and Mineralogical properties. Am Soc Agron, Madison. W.I, United States of America. 149-157

Rietz, D. N., and R. J. Haynes. 2003. Effects of irrigation-induced salinity and sodicity on soil microbial activity. Soil Biology and Biochemistry 35: 845-854.

Ross, M., M. T. Hernandez, and C. Garcia. 2003. Soil microbial activity after restoration of semi arid soil by organic amendments. Soil Biology and Biochemistry 35: 463-469.

Shah, R. U., M. Abid, F. Qayyum, and R. Ullah. 2015. Dynamics of chemical changes through production of various composts/vermicompost such as farm manure and sugar industry wastes. International Journal of Recycling of Organic Waste in Agriculture 4:39-51.

Steel, R. G. D., J. A. Torrie, and D. A. Dickey. 1997. Principles and Procedures of Statistics. 3rd McGraw Hill Book Corporation. Inc., New York, USA. 428-434.

Tajeda, M., M. T. Hernandez, and C. Garcia. 2006. Application of two organic amendments on soil restoration: Effects on the soil biological. 
properties. Journal of Environmental Quality 35: 1010-1017

Tate, R. L. 1987. Soil organic matter: Biological and Ecological Effects. Wiley, New York.

Ullah, R., G. Murtaza, A. Ghafoor, and S. Ullah. 2012. Improving the performance of wheat (Triticum aestivum L) by seed priming in salt affected soils irrigated with saline sodic water. Journal of Animal and Plant Sciences 22 (4): 10551059.

Ullah, R., M. I. Lone, K. S. U. Khan, S. M. Mehdi, and M. A. Qazi. 2013. Effect of cropping systems and seasonal variations on soil microbial biomass and enzymatic activities in arid soils. Journal of Animal and Plant Sciences 23(2): 493-499.
Ullah, R., M. I. Lone, S. Ali, and S. Hussain. 2009. Soil water variation under different cropping patterns on sloppy lands in Punjab. Soil $\mathcal{E}$ Environment 28(2): 156- 161.

Ullah, R., M. I. Lone, S. M. Mian, S. Ali, K. S.U. Khan, A. A. Sheikh, and I. Ali I. 2012. Impact of seasonal variations and cropping systems on soil microbial biomass and enzymatic activities in slope gradient moisture stressed soils of Punjab-Pakistan. Soil \& Environment 31(1): 21-29

Yang, L., T. Li, F. Li, J. I. I. Lemcoff, and S. Cohen. 2008. Fertilization regulates soil enzymatic activity and fertility dynamics in a cucumber field. Scientia Horticulturae

116:

21-26. 